\title{
Regulation, Deregulation and Bank Marketing in Nigeria
}

\author{
Imoh E Akpan
}

Department of Banking and Finance, University of Uyo, Nigeria

\section{ABSTRACT}

Bank marketing is deregulation friendly in Nigeria. This observation derives from the emergence of strong marketing orientation in banks following the SAP-induced liberalization of 1989. Advertising, product development/ innovation, up-front payment of interest on deposit and personal service that came with liberalization, started to wane in 1993 when government reintroduced some controls. However, marketing must not be seen as a tool needed only in a liberalized environment. It is necessary even in control regimes.

JEL G 21

\section{INTRODUCTION}

To a keen follower of Nigeria's banking development, two issues prompt sharp attention. They are regulation and deregulation. By banking regulation, we mean the imposition of control measures by the monetary authority(ies) with regard to how the banks, on the one hand, and the public with whom they conduct business, on the other hand, are to exercise their defined (something implied) duties, responsibilities and rights. The intention of government in approving and mounting the associated measures is not unrelated to its desire to lay a sound foundation for efficient and effective financial performance in the light of the pivotal role the banks play in the savings - investment process and, by extension, in economic development.

Deregulation of banking denotes the contrary and defines'a conscious lessening and/or removal of controls on the banks thus allowing them some freedom to do their business their own way, relying on the market forces (demand and supply) as they accept from and extend credit facilities to customers (Ojo, 1993; ADB, 1995; Fry, 1988; Agu, 1988). Controversies are however rife on whether the state should regulate banking activities et all. Dooley and Mathieson (1987) and Shaw (1973) do not see any virtue in government's control of banking 
operations; to them, the banks should be set free and allowed to exercise discretion in the conduct of their business.

The two perspectives (regulation and deregulation) carry some implications for bank marketing and point to a long history that predates the independent Nigeria. Initially, there was no legal framework for banking. However in 1952, the colonial government promulgated the first banking law, the Banking Ordinance (Nwankwo, 1980). Subsequently, the period spanning 1952 and 1970 witnessed a much more regulated banking environment with no less than four laws passed (details given in section 2). Similar development, through in a lesser degree, followed in the 1970s. However, in the 1980s, a sharp contrast set in when government introduced a deregulation programme that systematically changed the face of banking. This article is written to address the two fronts (regulation and deregulation) and their impact on and implications for bank marketing.

In addressing its subject matter, the article divides into four sections. Following this introduction (section 1), section 2 traces the history of banking in Nigeria, and reviews the universe of its regulation and deregulation. This is done to give readers the background of the Nigerian banking system. In section 3 how bank marketing fared under the two regimes; we emphasize the activities of commercial and merchant banks. Other banks are not considered here, seeing that their operations are relatively limited in scope, often not prominent enough to reflect the ebb and flow of economic activity. Section 4 contains some policy implications and concluding remarks.

The judgement of the impact of regulation and deregulation on bank marketing is based on a number of variables such as personal service, product development, advertising for business and information technology. A chronological framework that weaves the evolutionary trends of the banks against the enabling/regulatory laws and policies provides a means to explore bank marketing before and after the Structural Adjustment Programme (SAP) of 1986.

\section{BANKING: DEVELOPMENT, REGULATION AND DEREGU- LATION}

\subsection{Development}

Available records show that the history of banking in Nigeria traces back to 1892, when the African Banking Corporation (ABC) is said to have been established in Lagos to offer banking services to expatriate companies that existed at the time (Nwankwo, 1980). In 1894, the Bank of British West Africa 
(now First Bank) was founded and made to take over the affairs of $\mathrm{ABC}$. It took 18 years thereafter before another bank, Barclays Bank, Dominion, Colonial and Overseas (now Union Bank), came into being. In 1933, the National Bank of Nigeria was founded and in 1949, what is now the United Bank for Africa was established, its original name being the British and French Bank. In-between them there were other (indigenous) banks, but this development was short-lived as a spate of failures jolted customers and jeopardized the economy.

It is also on record that not less than 20 banks failed between 1930 and 1952 (Nwankwo, 1980: 46). Moreover, between 1947 and 1952 (a period often referred to as the free banking period) no less than 185 banks were granted registration of which 145 took place in 1947 and 40 in 1952. A point to note is that most of these banks were indigenous; they lacked a solid capital base, had weak administrative machinery and low patronage compared with their expatriate counterparts. Expatriate banks were favoured; not only were they properly funded by their parents, but quality staff were often sent from Britain to manage their affairs. Foreign commercial and industrial companies were ever ready to buy their services. In comparative terms, indigenous banks were virtually not there, and a few that operated were severely constrained.

After 1952, the development in the banking system became cautious. The caution spanned the 1960 s and was sustained into the $1970 \mathrm{~s}$ - with some improvement. In 1960, there were about six banks, the number increased to 15 in 1970 (14 commercial banks and one merchant bank), 22 in 1975 (17 commercial banks and five merchant banks), 26 in 1980 (20 commercial banks and six merchant banks). There was a sharp increase in 1985, when the number of commercial banks jumped to 28 and that of merchant banks to 12 , thus giving a combined figure of 40 for the two banking groups. The situation remained unchanged in 1986 except that one commercial bank was added to the list (CBN, 1994).

A dramatic change in bank registration took place between 1987 and 1990 . Five commercial and four merchant banks were registered in 1987 alone, eight in 1988, five and 10 in 1989, 11 and 15 in 1990, seven and five in 1991 respectively. In aggregate terms, Nigeria had $50,66,81,106,119$ and 120 banks in those years, the respective incremental rates being $22 \%, 32 \%, 12 \%$ and $0.8 \%$. The figure of 120 was retained in 1992 , however, the collapse of some banks brought the number down to 119 in 1993, 117 in 1994 and 115 in 1995. In February 1998, 26 banks ( 12 commercial and 13 merchant) had their licences revoked, thus reducing the number of banks further to 89 (Table 1, Appendix A). 


\subsection{Regulation and Deregulation}

The two concepts were stated in section 1 , and it was noted that they are always in conflict. Until recently, developing countries believed in the magic power of the state (government) in creating the desired direction for the economy. The banking system, being crucial in the scheme of development, often becomes the first to fall under governmental control. So it has been in Nigeria too.

In the wake of the dismal consequences of pre-independence free banking, governmental control of banking business was initiated in 1952. The Banking Ordinance of that year served to check the indiscriminate registration of banks, that resulted in widespread failures as noted above. The feeling was that the banks failed because they were given too much freedom in terms of capital requirement and general business conduct. Thus banks were required by the Ordinance to register before the commencement of business. A sum of $\$ 25000$ was fixed as the minimum paid-up capital, authorized capital was $\$ 50000$ for indigenous and $\mathbf{2} 20000$ for expatriate banks. In addition, every bank was required to create a reserve fund into which $20 \%$ of annual profits was to be paid until the fund equalled the paid-up capital. Each bank was to maintain adequate liquidity, not to pay dividends until capitalized expenditure was written off, not to lend on the security of its shares, and not to grant credit of more than $\$ 600$ to its directors.

These provisions were later toughened when it became evident that bank failures were not abating. Government then enacted another Ordinance in 1958. In it, the minimum paid-up capital for indigenous banks was increased to $\$ 50000$ while that of expatriate banks was fixed at $\$ 400000$. Still in 1958 , the Central Bank of Nigeria (CBN) Ordinance was promulgated. The Ordinance which created the CBN also gave it the power to administer other banks, to curb the failures that were staring the country in the face. In 1961 and 1962 , there were amendments to the banking laws to "deal with issues relating to liquidation and capital adequacy of banks" (Ojo and Oloyede, 1998: 6).

In 1969, another law, the Banking Decree served to raise the paid-up capital of indigenous banks to 600000 and that of expatriate banks to 1.5 million. In addition, banks were to maintain a reserve ratio of $1: 10$ between their paid-up capital plus statutory reserves and total deposits; they were not to openly campaign for deposits; were to operate under a regulated interest rate system where upper and lower limits were prescribed for them by government.

The financial markets that might have facilitated banking development were poorly developed and rigidly controlled. In the money market, government 
securities dominated, banks were not allowed to invest in corporate securities in the capital market.

By and large, before 1986 the banking system was heavily regulated, and government extended its monitoring hand to all aspects of banking, the prime target being interest rates which were fixed with minor variations. Lending and borrowing rates ranged between $9.5 \%-13 \%$ and $7.5 \%-8 \%$ respectively, and banks were required to maintain a prescribed ceiling on their annual credit expansions. In 1983, they were not permitted to advance credit beyond the prescribed ratios of $25 \%$ for big and $35 \%$ for small banks over their 1982 total loans and advances. (Previously the ratios were $30 \%$ and $40 \%$, and had remained so since the 1978/79 fiscal year.) However, smaller banks with loan portfolios not exceeding $\$ 1000$ were allowed to increase their lending up to $35 \%$ or to $60 \%$ of their total deposits, whichever was the higher. (Total deposits excluded government lodgings with maturity of less than six months.)

Sectorally, lending by banks was also not discretionary. Prescribed ratios were always readily determined by the CBN on behalf of government. Between 1980 and 1985, allocational ratio ranges were as follows (Akpan and Ayandele, 1999):
Agriculture
$8 \%-10 \%$
Export
$2 \%-3 \%$
Domestic trade
$19 \%-11 \%$
Overall productive sector
$59 \%-60 \%$

The period 1986 to 1993 witnessed a great change in the complexion of Nigerian banking. Within the framework of an unprecedented restructuring programme (Structural Adjustment Programme), governmental control of banking declined opening previously closed doors to banking and encouraging sundry entrepreneurs to join the system.

The removal of regulatory controls was indeed phenomenal, introducing new and unconventional banks, lifting the interest rate ceiling thus allowing market forces to determine deposit and lending rates, and freeing banks to campaign for business which caused rapid growth in the volume of deposits (Ojo, 1993). Government relinquished its ownership interest in commercial and merchant banks, withdrew public sector deposits from the banks and introduced an auctioning system in the sale of treasury bills. 


\section{MARKETING BANK SERVICES}

In a book that details the structure of the Nigerian financial system in the 1970s, Nwankwo (1980) described bank marketing as the conscious attempt by a bank to identify the financial needs of its customers, with a view to packaging its services in ways that would meet these needs at a profit. Need identification as used here, presupposes a profile of the customer's background, emphasizing his income bracket, business dealings as well as the opportunities and threats presented by the environment, both internal and external. However, Nwankwo was quick to add that Nigeria's banking market was a seller's market. Bank officers knew that customers would come to them, first because of the paucity of banking facilities and, second, because of their customers' ignorance that their support was crucial for the survival of the bank. Customers should rather have been sought by the banks, not the other way round. In the event, banks exploited the supply shortfall to dictate to their customers, showing little or no interest in personal service which is normally crucial in a business like banking - where trust is the watchword that breeds confidence and attracts patronage.

Nwankwo's observations were supported in a 1996 review of banking developments prior to the deregulation of the late 1980s. Akpan (1996) the reviewer, was quick to point out that the pre-deregulation banking caused banks to operate in "straitjacket", always waiting for customers to call on them, taking little initiative to reach out for business.

The banks could not have done better in a regulated framework that prescribed how they were to carry out almost every aspect of banking. We may recall that they were forbidden to advertise for business and invest in company shares, and that interest rates were fixed for them. Mixed with the limited number of banks which made customers scramble for the existing few, the controls engendered an uncaring attitude in bank staff, who would rather delight in long customer queues and an enormous bureaucracy in bank transactions. Wadiri (1981), looking at the problem at an annual seminar organized by the Nigerian Institute of Bankers (NIB) in 1980, summarized it as follows:

(a) poor counter services arising from a low degree of efficiency by bank officials and the inability of Nigerian banks to adopt innovations which have eased bank services elsewhere in the world;

(b) indifferent and discourteous attitude of bank staff;

(c) the absence of a convenient network of bank branches in most rural parts of the country;

(d) the slow procedure in granting bank facilities;

(e) cumbersome processes associated with the opening of accounts;

(f) low capital base; 
(g) the irregular issue of statements of accounts.

The above inefficiencies were seen by Wadiri as particularly unfortunate in view of the fact that the ultimate business of the bank is service predicated on promptness, efficiency and honesty. Difficult attempts to lodge and withdraw money at the banks where characteristic, occasionally resulting in the physical collapse of people in the queues and even subsequent loss of life. A number of them were driven into informal finance, noted for the freedom of entry and simplicity of operation (Bauman, 1995). Excuses for this were many. Wadiri (1981: 163) again has this to say:

... most routine business invariably involves a long period of waiting. In some cases, the waiting has to be undertaken in overcrowded and illventilated banking halls without comfortable seats. Added to this is the irritating indifference and brazen rudeness many customers endure from bank staff.

In the words of Nwankwo (1980:66):

It could take as much as an hour or more to refer a cheque and in some cases, one appears to be left with the impression that the counter staff take pride in the long queues and the number of people seeking their custom. Mail transfers take as long as three to four weeks to reach their destination within the country and almost as long before the beneficiary is finally paid in the case of cash payments.

A dramatic change however came in 1989 when, at the order of government, the banking system was deregulated. The deregulation ignited a new marketing orientation which made banks compete openly for business by placing adverts in various media, offering different rates of interest to customers (depending on how they perceived them and the volume of business the customers offered) and recruiting attractive and mentally sharp personnel to deal with the emergent and growing market. Between 1989 and 1992, adverts of diverse wording and intentions found their ways into the electronic and print media, pleading with the public for patronage. Formerly absent, official vehicles of banks began to wear identification symbols, all in an attempt to woo customers.

More importantly, new products were introduced into the banking market and older ones (very limited in number) were repackaged for greater appeal. Electronic fund transfers, credit cards, up-front payment of interest, computerization of activities, currency counting machines and the like, became entrenched in banking practice and narrowed the gap between Nigerian and foreign banking, thus attracting more people into the banking culture. 
The sharp increase in the business of banking did not take long to reveal its weak personnel base. Swift and unprecedented recruitment of staff became a feature of the banking boom. Labour turnover increased, witnessing, in most cases experienced staff leaving the bigger and older banks for the smaller and newer ones, that were ready to pay more to acquire mature skills in order to take advantage of the potential of the deregulated economy (Akpan and Ayandele, 1999). Also, the universities and polytechnics harbouring people with a financial background lost them to the banks.

The boom had its own side-effects. Fraud became prolific. The expected loss to fraud by commercial and merchant banks was estimated to have been $\$ 2167$ million between 1989 and 1997 (Table 11, Appendix A). Commercial banks were dominant, sharing 075 million between them; merchant banks lost $\$ 92$ million. In addition to fraud, widespread financial distress struck the banking system. It first affected eight banks in 1991; the number grew to 42 in 1994, 60 in 1995, 41 in 1997 and provisionally 15 in 1998 (NDIC, 1998).

The combined effect of the two problems (fraud and distress) in 1993 made government introduce what is called "guided deregulation" a "two way traffic" in which regulation and deregulation are woven together for a sounder financial performance. Government, while deregulating the banks, maintains some control to check excesses on the part of the banks, some of which may overstep their bounds in exercising their freedom.

The banks are almost brought to status quo (regulation era); they become cautious once again lessening advertising, divesting from product development, relaxing employee recruitment and training, among other functions. These happen in spite of the fact that governmental measures do not affect the variables except interest rate (ceiling reintroduced), bank registration (embargo placed) and up-front payment of interest (abolished).

\section{POLICY FALLOUT/CONCLUSION}

The foregoing discussion indicates that bank marketing is deregulation friendly at least, in the context of Nigeria. What never took place when the banking system was regulated, became evident between 1989 and 1992 (deregulation period) and began to thin out in 1993 when govermment brought back some controls. A worrying question that follows, is why did the marketing of bank services tend to deteriorate after 1992 when, in fact government's guided deregulation does not affect marketing variables like advertising, product development and improvement, personal services, etc? 
The banks themselves must answer this question, in the light of the fact that banking business is development oriented and it therefore becomes relevant whether banks operate in a regulated of deregulated environment. The two frameworks are meant to provide an enabling atmosphere for banking, depending on the objective of government that institutes them. Since marketing is needed in every aspect of business and, more importantly, in a personalized sector such as banking, the basic marketing variables discussed above do not need to wane as long as they remain within the law.

Is the deterioration in bank marketing due to a sharp fall in profits of the banks? Is it because of the slowing down of public patronage for banking on account of a loss of confidence in the banking system? Or is it out of incompetence or inadequacy of bank staff? These questions demand the urgent attention of bank managements. We proffer some suggestions.

On the first question, it is a challenge for the banks in Nigeria to break new ground, now that the potential of the foreign exchange market has declined. Such new ground in our view relates to the traditional role of the banks - that of financing real investment. Experience has shown that banks have been shying away from financing real investment (Akpan, 1999), their excuse being that its gestation period is long and could therefore not bring quick benefit. They rather finance commerce, often violating monetary policy rules when more than the allowed credit allocations made to this sector. In a typical developing economy such as Nigeria, the need to finance real investment cannot be overemphasized; the banks should realize this and adapt their credit policies accordingly. There are many investors in agriculture, manufacturing and construction begging for bank financing.

On liquidity squeeze (financial distress) we suggest that a concerted effort be made to re-capitalize the banks as demanded by the monetary authorities. The $\$ 500$ million minimum capital base is a sufficient cushion to support routine commitments like advertising, computerization, and product improvement and development. With a revamped liquidity position and subsequent improved marketing of services, the banks would more than ever before attract public confidence and patronage, which at present are not encouraging. Added to increased liquidity, proper credit management policies must be put in place to address the problem of maturity mismatch between deposit liabilities and loan assets.

Lastly, banks must embrace manpower development, always seeking to secure the best staff and getting ready to train them both on and off the job. The solution to incompetence, low productivity and impersonal service is a radical recruitment policy that hinges on professionalism and training. Banking is no 
more a free-for-all profession, harbouring people whose qualifications have little or nothing to do with the art and science of shifting money from the surplus economic units to deficit units in a manner that brings about economic growth and development. 


\section{APPENDIX A}

Table I: Growth of commercial and merchant banks (selected years)

\begin{tabular}{|l|c|c|c|c|c|c|c|c|c|c|c|c|c|c|c|c|c|}
\hline $\begin{array}{l}1970 \\
\text { No of } \\
\begin{array}{l}\text { Com- } \\
\text { mercial } \\
\text { Banks }\end{array}\end{array}$ & 14 & 17 & 20 & 28 & 29 & 34 & 42 & 47 & 58 & 65 & 66 & 66 & 66 & 64 & 65 & 64 & 51 \\
\hline $\begin{array}{l}\text { No of } \\
\text { Mer- } \\
\text { chant } \\
\text { Banks }\end{array}$ & 1 & 5 & 6 & 12 & 12 & 16 & 24 & 34 & 48 & 54 & 54 & 53 & 51 & 51 & 51 & 51 & 38 \\
\hline Total & 15 & 22 & 26 & 40 & 41 & 50 & 66 & 81 & 106 & 119 & 120 & 119 & 117 & 115 & 115 & 115 & 89 \\
\hline
\end{tabular}

Source: Akpan and Ayandele (1999: 78), NDIC Annual Reports and Statements of Accounts (1995-1998). 
Table II: Returns of banks on frauds and forgeries (1989 - 1997 million)

\begin{tabular}{|c|c|c|}
\hline Year & Amount involved & Expected loss \\
\hline \multicolumn{3}{|c|}{ Commercial banks } \\
\hline 1989 & 98.2 & 15.3 \\
\hline 1990 & 788.8 & 22.4 \\
\hline 1991 & 360.2 & 25.5 \\
\hline 1992 & 351.9 & 64.8 \\
\hline 1993 & 1377.2 & 241.0 \\
\hline 1994 & 2655.7 & 883.6 \\
\hline 1995 & 1006.3 & 226.4 \\
\hline 1996 & 1542.9 & 371.1 \\
\hline 1997 & 3590.3 & 224.5 \\
\hline Sub total & 11771.5 & 2074.6 \\
\hline Year & Amount involved & Expected loss \\
\hline \multicolumn{3}{|c|}{ Merchant banks } \\
\hline 1989 & 6.7 & 0.1 \\
\hline 1990 & 15.4 & 0.03 \\
\hline 1991 & 28.3 & 1.2 \\
\hline 1992 & 59.8 & 8.3 \\
\hline 1993 & 41.9 & 5.3 \\
\hline 1994 & 743.7 & 67.1 \\
\hline 1995 & 5.1 & 2.8 \\
\hline 1996 & 57.8 & 4.2 \\
\hline 1997 & 187.6 & 2.9 \\
\hline Sub total & 1146.3 & 91.9 \\
\hline Grand total & 12917.8 & 2166.5 \\
\hline
\end{tabular}

Source: Akpan and Ayandele (1999: 84); NDIC Annual reports and statements of Accounts, 1996-1997.

\section{REFERENCES}

1 ADB (1995) African Development Report, African Development Bank: Abidjan.

2 AGU, C.C. (1988) Nigerian Banking Structure and Performance, Africana-Feb Publishers: Onitsha.

3 AKPAN, 1. (1996) "Management of Financial Distress: Implications for Individuals, Organizations and Economies", Nigerian Journal of Economic and Social Studies, 8(1): 53-64. 
4 AKPAN, I. and AYANDELE, I. (1999) "Conservatism versus Aggressiveness: a Review of Banking Development in Nigeria, 19801995", International Journal of Social Sciences, 1(1): 76-94.

5 BAUMAN, F.J.A. (1995) "Rotating and Accumulating Savings and Credit Associations: A Development Perspective", World Development, 23(3): 371-84.

6 CBN (1994), Statistical Bulletin, Lagos.

7 DOOLEY, M.P. and MATHIESON, D.J. (1987), "Financial Liberalization in Developing Countries", Finance and Development: 31-4.

8 FRY, M.J. (1988) Money, Interest and Banking in Development, The John Hopkins University Press: Baltimore.

9 NDIC (1995), Annual Report and Statement of Accounts, Abuja.

10 NDIC (1995) NDIC (1996) Annual Report and Statement of Accounts: Abuja.

11 NDIC (1997) Annual Report and Statement of Accounts: Abuja.

12 NDIC (1998) Annual Report and Statement of Accounts: Abuja.

13 NWANKO, G.O. (1980) The Nigerian Financial System, Macmillan: London.

14 OJO, A.T. and OLOYEDE, J.A. (1998) "Deregulation, Concentration and Profitability in the Nigerian Banking System", Nigerian Journal of Banking and Financial Issues, 1(1): 1-24.

15 OJO, M.O. (1993) A Review and Appraisal of Nigeria's Experience with Financial Sector Reform, CBN: Lagos.

16 SHAW, E. (1973) Financial Deepening in Economic Development, Oxford University Press: London.

17 WADIRI, B.P. (1981) "Marketing and Improving Bank Services" in Domestic and International Banking Services, CIBN: Lagos. 